\title{
COLLEGE STUDENTS' PERCEPTION OF SCHOOLOGY IN COMPUTER ASSISTED LANGUAGE LEARNING COURSE
}

\author{
Nugroho \\ Program of English Education, Faculty of Language and Art, University of Indraprasta PGRI \\ Jalan Nangka No. 58C Tanjung Barat, Jagakarsa, South Jakarta 12530 \\ bejo2210@gmail.com
}

\begin{abstract}
This study aims to determine the perceptions of students as prospective teachers of Schoology in Computer Assisted Language Learning (CALL) subject in undergraduate classes. Schoology is a web-based learning media commonly called the Learning Management System. Schoology is one of the free web platforms in the form of the social web and easy to use as Facebook. This study uses a qualitative descriptive method and approach with data collection method in the form of interviews. The interviewer interviewed nine informants, sixth-semester students in Computer Assisted Language Learning subjects with a Schoology discussion. Informants acted as instructors in their groups randomly selected. The results of the interview show that all informants already know the Schoology and its features. Informants will also use Schoology when they become teachers. The obstacle faced by $44 \%$ of students were when making material in the form of quizzes. They usually forget to arrange the quiz so the quiz does not appear on the student's account. The obstacle was to download the value and print it. However, overall, the students' perceptions of Schoology in CALL courses were ethical. This research will be further developed at the school level, Schoology, in the view of teachers and students.
\end{abstract}

Keywords: perceptions, Schoology, technology, CALL

\begin{abstract}
ABSTRAK
Penelitian ini bertujuan untuk mengetahui persepsi mahasiswa sebagai calon guru terhadap Schoology pada mata kuliah Computer Assisted Language Learning. Schoology adalah media pembelajaran berbasis web yang biasa disebut dengan Learning Management System. Schoology merupakan salah satu laman web gratis yang berbentuk web sosial dan mudah digunakan seperti Facebook. Penelitian ini menggunakan metode dan pendekatan deskriptif kualitatif dengan metode pengumpulan data berupa wawancara. Pewawancara mewawancarai sembilan informan yaitu mahasiswa semester enam pada mata kuliah Computer Assisted Language Learning dengan pembahasan Schoolgy. Informan berperan sebagai instruktur di kelompoknya yang dipilih secara acak. Hasil wawancara menunjukkan bahwa seluruh informan telah mengetahui Schoology dan fitur-fiturnya. Informan juga akan menggunakan Schoology ketika menjadi guru kelak. Kendala yang dihadapi 44\% mahasiswa adalah ketika membuat materi berupa kuis. Mereka biasanya lupa untuk mengatur kuis sehingga kuis tidak muncul di akun mahasiswa. Kendala yang lainnya adalah untuk mengunduh nilai dan mencetaknya. Namun secara keseluruhan persepsi mahasiswa terhadap Schoology
\end{abstract}


pada mata kuliah CALL adalah baik. Penelitian ini akan dikembangkan di tingkat sekolah, Schoology dalam pandangan guru dan siswa.

Kata Kunci: persepsi, Schoology, teknologi, CALL

\section{INTRODUCTION}

Technology has become an important part of people's lives (Costley, 2014). Almost all aspects of life today involve the role of technology. The development of science and technology also has an impact on education and learning. There have been many changing aspects of education due to the development of information technology (McKeachie, 1994). The importance of using technology in the field of education indicated the demand for competencies that must be mastered by students in the 21 st century, namely the ability to utilize information media effectively and integrate technology in learning (Greenstein, 2012).

One form of technology that is widely used today is social networking. There are many social networking sites that are accessed by people at various age levels such as Facebook, Twitter, LinkedIn, Edmodo, Schoology, Kelase, and so on. Initially, social networking sites were only seen as a way or tool for friends. However, over time social networking sites have added benefits to being tools for sharing information (McClain, Brown, \& Price, 2015). In 2008 a social networking site called Edmodo was developed specifically to meet the needs in the field of education (Manowong, 2016).

Schoology is a school-based environment that was developed by Nicolas Borg and Jeff O'Hara in 2008. Schoology is intended for teachers, students, and parents. Schoology has more complete specifications than Edmodo and Moodle. Schoology is complete with a variety of learning tools that are done in the real world, ranging from checking attendance, tests, and quizzes to student task collection (Amiroh, 2013). Schoology allows the collaboration of various individual, group, and class discussions so that the Schoology is suitable as a supporting learning media of e-Learning. The attitude of students towards the use of Schoology as a learning media influences the success of students in learning. The attitude of students shows how to respond to an object consistently (Dayakisni \& Hudaniyah, 2006).

The control of information technology, especially the Schoology application, has not been maximized. Lecturers often experience problems when teaching with Schoology online. Internet network access is also considered still expensive and slow by students. It makes online learning disrupted.

Research results of Teacher professionalism in implementing information and communication technology in Nganjuk district show that elementary, middle, and high school teachers lack the mastery of Information and Communication Technology (Syukur, 2014). Based on the results of a survey conducted at SMK Negeri 1 Sukoharjo, it was shown that Digital Simulation learning was not optimal. That the use of e-learning in learning is not maximal (Tigowati, Efendi, Agus, Budiyanto, \& W, 2014). Khoirunnisa's research in the SMPN throughout Bekasi concluded that teacher competence was quite good, except evaluation and learning outcomes, there were still teachers who 
could not accept pluralism and multiculturalism and the lack of knowledge of teachers about information technology (Khoirunissa, 2012). The development of the ongoing professionalism of certified teacher educators in technical vocational schools in Greater Malang is still relatively low (Sujianto, 2013). The internal problem lies in the educator himself because he is often found by educators who do not fulfill the qualifications as teachers or lecturers so that in his teaching practice, it becomes less exciting and not inspiring for his students. Second, external problems. In this case, the government as the decision-maker, must improve and evaluate the aspects of education that are lacking (Rohman, 2016).

The students' perceptions of their educational environment have been studied at all levels of educational systems (Arzuman H, 2010). Perception is a direct response from a person's absorption or process in knowing several things through sensing (Poerwadarminta, 1990). Therefore, the researcher wonders what the student's perceptions on Schoology are. It is essential to ensure that the learning done is fun, motivating, and meaningful for students.

\section{METHOD}

In this study, the research study used is a qualitative approach because problems related to humans are fundamentally dependent on observation. According to (Moeleong, 2010):

"Qualitative research is research that intends to understand the phenomenon of what is experienced by the subject of research such as behavior, perception, motivation, actions and others holistically and by way of description in the form of words and language, in a special context that is natural and with utilizing various natural methods."

While the definition of a qualitative approach, according to (Sugiyono, 2016):

"Qualitative research methods are methods based on the philosophy of postpositivism, while to examine natural objects, where the researcher is a key instrument, the technique of data collection is done by triangulation (combined). Data analysis is inductive or qualitative, and research results emphasize meaning rather than generalization".

Descriptive methods were chosen because the research carried out was related to ongoing events and concerning current conditions. (Nazir, 2014) described, "a descriptive method as a descriptive method is a method in examining the status of a human group, a subject, a set of conditions, a system of thought or class of events in the present. The purpose of this descriptive study is to make a description, description or painting systematically and the relationship between the phenomena investigated".

The focus of this research is the Students' Perception of Schoology Implementation in Computer Assisted Language Learning courses at the 6th semester of 2019 Universitas Indraprasta Jakarta students. Before applying the application of Schoology, students participated in Computer Assisted Language Learning courses. It was delivered offline learning and webbased online learning. The students will conduct learning simulations with roles as administrators, educators, and 
students. Thus students can apply the application of Schoology.

The research instrument in qualitative research is the researcher itself, (Sugiyono, 2016) stated that qualitative researchers as human instruments, serves to determine the focus of research, choose informants from data sources, collect data, assess data quality, analyze data, interpret data and make conclusions for his findings. (Basrowi, 2008) stated that using humans as a tool (human instrument) is more likely to make adjustments to the realities that exist in the field and relate directly to the respondent or other objects so that they can understand the relation between reality in the field.

According to Lofland and Lofland (Moeleong, 2010) the primary data sources in qualitative research are words and actions; the rest are additional data such as documentation and others. Even though it is said that the source of data outside of words and actions is additional data, it is clear that the data source cannot be ignored data collection techniques with interviews. The interviews were structured in a manner similar to informal conversations. (Nasution, 1996) stated, "Interviews in naturalistic qualitative research, especially for beginners, are usually unstructured. The aim is to obtain detailed and in-depth information about the views of others".

Qualitative research obtains data from various sources, using various data collection techniques that are carried out continuously until the data is saturated. Data analysis is done by organizing data, describing it into unit units, synthesizing, arranging into patterns, choosing which ones are important to learn, and making conclusions that will be told to others.

The data analysis technique

refers to Huberman's opinion
(Sugiyono, 2016) mentioned that the activities in qualitative data analysis are carried out continuously until the data is saturated. Systematically the steps can be explained as follows:

1. Data Reduction

Reducing data means choosing the main things, focusing on the essential things, looking for themes and patterns and throwing out unnecessary ones. Thus the reduced data will provide a clear picture and make it easier for researchers to collect further data. Apart from that, researchers also provide codes in certain aspects to facilitate the process of recording in the field.

2. Data Display

After the data has been reduced, the next step is to create a data display. Display data is a way of classifying data into groups that are presented either in the form of graphs or matrices so that data is easy to read and understand and describes the whole or certain parts of the research.

3. Draw Conclusions and Verification Drawing conclusions is done from the beginning to the end of the research process to make it easier for researchers to get the meaning of each data that is still collected. The conclusions taken were initially temporary and even in doubt. Therefore, conclusions were always verified throughout the study to be a level of trust in research.

In analyzing data, researchers interpret or interpret data that had been described and compare it with relevant theories so that the data has meaning.

\section{RESULTS AND DISCUSSION}

\section{Identification of Informants}

The subjects of this study were 6thsemester students who were studying Computer Assisted 
Language Learning courses with Schoology. Informants 1 through 9 informants were students randomly selected. The following is the informant's data:

Table 1

Informants

\begin{tabular}{clc}
\hline No. & Informan & $\begin{array}{l}\text { Nomor Pokok } \\
\text { Mahasiswa }\end{array}$ \\
\hline 1. & Informan 1 & 201612500524 \\
2. & Informan 2 & 201612500489 \\
3. & Informan 3 & 201612500028 \\
4. & Informan 4 & 201612500154 \\
5. & Informan 5 & 201612500113 \\
6. & Informan 6 & 201612500094 \\
7. & Informan 7 & 201612500737 \\
8. & Informan 8 & 201612500662 \\
9. & Informan 9 & 201612500219 \\
\hline
\end{tabular}

\section{Description of Research Data}

Data is something that is obtained through a data collection method. It will be managed and analyzed by a precise method. In this study, data was obtained through interviews. The following is the core of the interview:

Table 2

Interviews

\begin{tabular}{cl}
\hline No. & \multicolumn{1}{c}{ Questions } \\
\hline 1. & $\begin{array}{l}\text { How do you know web-based learning } \\
\text { models? }\end{array}$ \\
2. & $\begin{array}{l}\text { Did you obtain web-based learning } \\
\text { information from lecturers? }\end{array}$ \\
3. & $\begin{array}{l}\text { Did you obtain web-based learning } \\
\text { information from other sources? }\end{array}$ \\
4. & $\begin{array}{l}\text { What do you need to prepare to run the } \\
\text { application of web-based learning? }\end{array}$
\end{tabular}

5. Do you know Schoology?

6. Do you know Schoology features?

7. Do you any problems with making the course/class?

8. Do you have any problems with uploading material?

9. Do you have any problems with making quizzes?

10. Do you have any problems with making gradebooks?

11. Do you have any problems with printing results?

12. Do you want to use Schoology when you become a teacher?

After conducting interviews with all informants with the above questions, the data obtained is as follows:

Table 3

Perception

\begin{tabular}{|c|c|c|c|c|c|c|c|c|c|c|c|c|}
\hline \multirow{2}{*}{$\begin{array}{c}\text { Info } \\
\text { rma } \\
\mathrm{n}\end{array}$} & \multicolumn{12}{|c|}{ Responses } \\
\hline & 1 & 2 & 3 & 4 & 5 & 6 & 7 & 8 & 9 & $\begin{array}{l}1 \\
0\end{array}$ & $\begin{array}{l}1 \\
1\end{array}$ & $\begin{array}{l}1 \\
2\end{array}$ \\
\hline 1 & $\mathrm{Y}$ & $\mathrm{Y}$ & $\mathrm{Y}$ & $\mathrm{Y}$ & $\mathrm{Y}$ & $\mathrm{Y}$ & $\mathrm{Y}$ & $\mathrm{Y}$ & $\mathrm{N}$ & $\mathrm{N}$ & $\mathrm{N}$ & $Y$ \\
\hline 2 & $\mathrm{Y}$ & $\mathrm{Y}$ & $\mathrm{Y}$ & $\mathrm{Y}$ & $\mathrm{Y}$ & $\mathrm{Y}$ & $\mathrm{N}$ & $\mathrm{N}$ & $\mathrm{N}$ & $\mathrm{N}$ & $\mathrm{Y}$ & Y \\
\hline 3 & Y & Y & $\mathrm{Y}$ & Y & $\mathrm{Y}$ & $\mathrm{Y}$ & $\mathrm{N}$ & $\mathrm{N}$ & Y & $\mathrm{N}$ & Y & Y \\
\hline 4 & $\mathrm{Y}$ & Y & $\mathrm{Y}$ & $\mathrm{Y}$ & $\mathrm{Y}$ & $\mathrm{Y}$ & $\mathrm{N}$ & $\mathrm{N}$ & $\mathrm{N}$ & $\mathrm{N}$ & $\mathrm{N}$ & Y \\
\hline 5 & Y & Y & Y & Y & $\mathrm{Y}$ & $\mathrm{Y}$ & $\mathrm{N}$ & $\mathrm{Y}$ & Y & $\mathrm{N}$ & Y & Y \\
\hline 6 & $\mathrm{Y}$ & Y & $\mathrm{N}$ & $\mathrm{Y}$ & $\mathrm{Y}$ & $\mathrm{Y}$ & $\mathrm{N}$ & $\mathrm{N}$ & $\mathrm{N}$ & $\mathrm{N}$ & $\mathrm{Y}$ & Y \\
\hline 7 & $\mathrm{Y}$ & $\mathrm{Y}$ & $\mathrm{Y}$ & $\mathrm{Y}$ & $\mathrm{Y}$ & $\mathrm{Y}$ & $\mathrm{N}$ & $\mathrm{Y}$ & $\mathrm{N}$ & $\mathrm{N}$ & $\mathrm{N}$ & $\mathrm{Y}$ \\
\hline 8 & $\mathrm{Y}$ & Y & $\mathrm{N}$ & Y & $\mathrm{Y}$ & $\mathrm{Y}$ & Y & $\mathrm{Y}$ & $\mathrm{Y}$ & $\mathrm{Y}$ & $\mathrm{N}$ & Y \\
\hline 9 & $\mathrm{Y}$ & $\mathrm{Y}$ & $\mathrm{Y}$ & $\mathrm{Y}$ & $\mathrm{Y}$ & $\mathrm{Y}$ & $\mathrm{N}$ & $\mathrm{N}$ & $\mathrm{N}$ & $\mathrm{N}$ & $\mathrm{N}$ & $\mathrm{Y}$ \\
\hline
\end{tabular}

\section{Description of Data Analysis Results}

The results of the interviews that have been conducted are illustrated in the following table form:

Table 4

Results

\begin{tabular}{clc}
\hline No. & \multicolumn{1}{c}{ Perception } & Persentase \\
\hline 1. & Student Knowing the web-based learning model & $100 \%$ \\
2. & $\begin{array}{l}\text { Students Get web-based learning information from } \\
\text { lecturers }\end{array}$ & $100 \%$ \\
3. $\quad \begin{array}{l}\text { Students Get web-based learning information from other } \\
\text { sources }\end{array}$ & $78 \%$ \\
4. Students Know the preparation for the application of & $100 \%$ \\
& $\begin{array}{l}\text { 100\% web-based learning } \\
\text { 5. Students Know 100\% Schoology }\end{array}$ & $100 \%$
\end{tabular}


$\begin{array}{lll}\text { 6. Students Know the features - 100\% Schoology features } & 100 \% \\ \text { 7. students have problems making courses/classes } & 22 \% \\ \text { 8. students have problems uploading materials } & 44 \% \\ \text { 9. students have problems in making quizzes } & 33 \% \\ \text { 10. Students Have Problems Making Gradebook } & 11 \% \\ \text { 11. Students have problems in printing } 44 \% \text { results } & 44 \% \\ \text { 12. students will apply Schoology when they become } & 100 \%\end{array}$

From the table data above, it is clearly illustrated that 9 informants had responded to 12 interviewer's questions. From the table, it is also known that all informants have known web-based learning. All informants get information about web-based learning from lecturers and as many as $78 \%$ of informants also get information from other sources. All information also knows or recognizes web-based learning with its features. Even though they are familiar with Schoology and its features, there are still $22 \%$ of informants who still have problems in making classes. Whereas in uploading the material, there were $44 \%$, especially on the quiz setting for publishing and the slow internet access. In making quizzes, there were still 33\% of informants who had problems in multiple-choice and matching quizzes. The informant needs to try several times to understand it. There is $11 \%$ of informants had problems in making gradebooks when Grade Setup. Informants also have problems with printing results, especially the way to export from Schoology to ms. Excel then prints it. The encouraging thing is that all informants will use Schoology when becoming teachers as web-based learning media.

\section{CONCLUSION}

From the results and discussion above it can be concluded as the followings:

1. Good perceptions obtained from the results of interviews proved that almost all respondents answers were satisfactory.

2. All informants already knew what is Schoology and its features.

3. They will use Schoology when they become teachers.

4. The first obstacle faced by some informants was uploading material because they forgot to set the quiz.

5. The second obstacle is downloading and printing. This is because students must edit the results that have been downloaded.

6. Common constraints also occur in web-based learning, namely a slow internet network, so that activities also become disrupted.

Although the results of this study show that the good perceptions of students on Schoology. The students got benefit from it. Several weaknesses limited the research. First, the sample size of a student may be considered to be insufficiently large enough to indicate sufficiently strong results, whether the same results will be obtained if the number of samples is enlarged. Larger sample sizes are 
needed in future research. The second weakness is the presence of uneven students so that informants were randomly selected from students whose attendance was more than $85 \%$. A nonoptimal presence makes students not understand the material because learning is still based on face to face.

The third weakness is the slow internet network, making students not optimal in learning this web-based learning material. This is a common concern because of the need for high internet facilities in this country.

\section{REFERENCES}

Amiroh. (2013). Under E-Learning, Edmodo, Moodle and Schoology. Retrieved from Amiroh.web.id: http://amiroh.web.id/

Basrowi, S. (2008). Memahami Penelitian Kualitatif. Jakarta: Rineka Cipta.

Costley, K. C. (2014). The Possitive Effects of Technology on Teaching and Student Learning. Arkansas: Arkansas Tech University.

Dayakisni, T., \& Hudaniyah. (2006). Psikologi Sosial. Malang: UMM Press.

Greenstein, L. (2012). Assessing 21st Century Skills - A Guide to Evaluating Mastery and Authentic Learning. California: Corwin A Sage Company.

Khoirunissa. (2012). Profil Kompetensi Guru Agama Islam SMPN di Kota Bekasi. Tarbawi, 205-216.

Manowong, S. (2016). Undergraduate Students' Perceptions of Edmodo as a Supplementary Learning Tool in an EFL classroom. Silpakorn University Journal of Social Sciences, Humanities, and Arts, 16(2), 137-161.
McClain, C., Brown, A., \& Price, G. (2015). Characterization Personified: Using Edmodo to Strengthen Student Interaction with Literature. Meridian: A K-16 School Computer Technologies Journal, 18, 1-19.

McKeachie, W. J. (1994). Teaching Tips 9th Edition. USA: Health and Company.

Moeleong, L. J. (2010). Metode Penelitian Kualitatif. Bandung: Remaja Rosdakarya.

Nasution. (1996). Metode Penelitian Kualitatif Naturalistik. Jakarta: Sinar Grafika.

Nazir, M. (2014). Metode Penelitian. Bogor: Galia Indonesia.

Poerwadarminta, W. J. (1990). Kamus Besar Bahasa Indonesia. Jakarta: Balai Pustaka.

Rohman, M. (2016). Problematika Guru dan Dosen dalam Sistem Pendidikan Nasional. Cendikia, 49-71.

Sugiyono. (2016). Metode Penelitian Pendidikan Pendekatan Kuantitaif, Kualitatif, dan R\&D. Bandung: Alfabeta.

Sujianto. (2013). Pengembangan Profesionalitas Berkelanjutan Guru Bersertifikat Pendidik di SMK Rumpun Teknologi seMalang Raya. Pendidikan Sains, 159-171.

Syukur, I. A. (2014). Profesionalisme Guru dalam Mengimplementasikan Teknologi Infomrasi dan Komunikasi di Kabupaten Nganjuk. Jurnal Pendidikan dan Kebudayaan, 3847.

Tigowati, Efendi, Agus, Budiyanto, \& W, C. (2014). E-Learning Berbasis Schoology dan Edmodo: Ditinjau dari Motivasi dan Hasil Belajar Siswa SMK. Elinvo, 49-5 